\title{
IMPACT OF WATER HYACINTH ON PROPERTIES OF CONCRETE MADE WITH VARIOUS GRAVEL TO DOLOMITE RATIOS
}

\author{
[AHMED SHABAN ABDEL HAY AND YASSER ABDEL GHANY FAWZY]
}

\begin{abstract}
Water hyacinth(W-H) has an adverse effect on Nile river in Egypt, it absorb a high quantities of water, it is need to serve the quantities arrived ( 55500 million $\mathbf{~ m}^{3}$ ) especially in this time, so by burning W-H it can used in concrete mix to reduce the permeability of concrete. In this study, the effect of $\mathrm{W}-\mathrm{H}$ on concrete properties ( freshhardened) were studied, slump of concrete as a fresh properties, compressive strength, splitting tensile strength as mechanical properties, mass transport by Isat , microstructure by XRD and thermal gravimetric analysis (TGA). This paper presents a study on the properties of concrete prepared with two aggregate types, namely gravel and dolomite. Various concrete mixes made with gravel and dolomite which blended with proportions $1: 0,0: 1,1: 1,1: 2$ and $2: 1$, respectively with different $\mathrm{W}-\mathrm{H}$ ratios of $0,0.5,1.0,2.0$ and $5.0 \%$ by mass of cement at $\mathrm{w} / \mathrm{c} \mathbf{0 . 5 0}$ for different mixes. The results showed that mechanical properties of concrete developed at $2 \% \mathrm{~W}-\mathrm{H}$ for different gravel/ dolomite ratios and mass transport properties of concrete enhanced at this ratio of W-H.
\end{abstract}

Keywords-Water hyacinth, compressive strength, mass transport, Concrete.

\section{Introduction}

Plant extracts contain a wide range of organic components. Extracts of plant based materials have been used as admixtures in altering the various properties of cement and many researches in this focal point have been constantly undertaken. Many research activities are undertaken elsewhere on possible ways of improving the quality of concrete. On one hand, bio-concrete accelerating admixture is developed as an alternative to calcium chloride component in cement. On the other hand, research on biobased retarding admixture of concrete for tropical environments is underway [1]. Consistency and setting time of cement is noted for $0,10,15$ and $20 \%$ replacement of water with hydro extract of water hyacinth and the mechanical properties of concrete have been carried out. Workability increased with increase in replacement percentage $(0-20 \%)$. Work is repeated with bio fine powder. The results showed a progressive increase in compressive strength with increase in percentage of replacement with bio admixture but delayed the setting time [2].

AHMED SHABAN ABDEL HAY

Faculty of Engineering, Beni-Suef University Egypt

\section{YASSER ABDEL GHANY FAWZY}

Faculty of Engineering, Beni-Suef University Egypt
[3] Studied the feasibility of using W-H as concrete admixture, whereas, [4] discussed the impact of $\mathrm{W}-\mathrm{H}$ as partial replacement of cement on concrete properties. Under the author knowledge, there is a lack of the influence of W$\mathrm{H}$ as an admixture on mass transport properties of concrete made with blending different coarse aggregates by various ratios, this study focused on the influence of $\mathrm{W}-\mathrm{H}$ on different properties of concrete made with various gravel dolomite ratios.

\section{Experimental Program}

\subsection{Materials}

Ordinary Portland cement (OPC) used in this investigation was delivered from "Beni- suef cement company", Type CEMI $42.5 \mathrm{~N}$. Testing of cement was carried out per the Egyptian Standard Specifications ESS 2421/2005 [5]. The chemical and physical analysis of this cement is presented in Table 1. Natural siliceous sand with fineness modulus 2.73 was used as a fine aggregate. Dolomite and gravel with 20 mm M.N.S were used as a coarse aggregate, the physical properties of coarse aggregates is presented in Table 2. Tap water used for mixing and curing. Water hyacinth brought from canal in Beni- suef was burned at 950 degree to convert to ash [4], the chemical analysis of $\mathrm{W}-\mathrm{H}$ is presented in Table 3. Twenty five mixes of concrete were prepared .The mix proportions of mixes considered in this program of study are shown in Table 4.

TABLE 1, Chemical and physical analysis of cement.

\begin{tabular}{|c|c|}
\hline Property & OPC \\
\hline Chemical composition, $\%$ & \\
\hline $\mathrm{SiO}_{2}$ & 20.56 \\
\hline $\mathrm{Al}_{2} \mathrm{O}_{3}$ & 5.59 \\
\hline $\mathrm{Fe}_{2} \mathrm{O}_{3}$ & 2.65 \\
\hline $\mathrm{CaO}$ & 63.13 \\
\hline $\mathrm{MgO}$ & 1.94 \\
\hline $\mathrm{Na}_{2} \mathrm{O}$ & 0.22 \\
\hline $\mathrm{K}_{2} \mathrm{O}$ & 0.6 \\
\hline $\mathrm{So} 3$ & 2.61 \\
\hline Bouge compounds, $\%$ & \\
\hline $\mathrm{C}_{3} \mathrm{~S}$ & 61 \\
\hline $\mathrm{C}_{2} \mathrm{~S}$ & 12.7 \\
\hline $\mathrm{C}_{3} \mathrm{~A}$ & 8 \\
\hline $\mathrm{C}_{4} \mathrm{AF}$ & 9.1 \\
\hline Finial setting time, min. & 135 \\
\hline Final setting time, min. & 300 \\
\hline
\end{tabular}


Proc. of the Third Intl. Conf. Advances in Civil, Structural and Mechanical Engineering- CSM 2015

Copyright (C) Institute of Research Engineers and Doctors, USA .All rights reserved.

ISBN: 978-1-63248-062-0 doi: 10.15224/ 978-1-63248-062-0-59

TABLE 2, Physical properties of coarse aggregate

\begin{tabular}{|c|c|c|c|}
\hline Type & $\begin{array}{c}\text { 24-hour } \\
\text { water } \\
\text { absorption, \% }\end{array}$ & $\begin{array}{c}\text { Specific } \\
\text { gravity }\end{array}$ & $\begin{array}{c}\text { Unit } \\
\text { weight } \\
\mathbf{K g} / \mathbf{m 3}\end{array}$ \\
\hline Gravel & 0.92 & 2.60 & 1885 \\
\hline Dolomite & 0.98 & 2.65 & 1665 \\
\hline
\end{tabular}

TABLE 3, Chemical analysis of water hyacinth.

\begin{tabular}{|c|c|}
\hline $\mathrm{SiO}_{2}$ & 23.30 \\
\hline $\mathrm{Al}_{2} \mathrm{O}_{3}$ & 4.23 \\
\hline $\mathrm{Fe}_{2} \mathrm{O}_{3}$ & 5.98 \\
\hline $\mathrm{CaO}$ & 17.4 \\
\hline $\mathrm{MgO}$ & 4.45 \\
\hline $\mathrm{SO}_{3}$ & 5.06 \\
\hline $\mathrm{TiO}_{2}$ & 0.61 \\
\hline $\mathrm{P}_{2} \mathrm{O}_{5}$ & 3.85 \\
\hline $\mathrm{Na}_{2} \mathrm{O}$ & 1.49 \\
\hline $\mathrm{K}_{2} \mathrm{O}$ & 7.43 \\
\hline $\mathrm{MnO}$ & 13.10 \\
\hline $\mathrm{BaO}$ & 0.21 \\
\hline $\mathrm{Cr}_{2} \mathrm{O}_{3}$ & 0.17 \\
\hline $\mathrm{Cl}$ & 7.1 \\
\hline L.O.I & 5.51 \\
\hline
\end{tabular}

\subsection{Mixture proportions}

Twenty five mixtures were tested in this research. These mixtures made with ratio of gravel to dolomite $=$ 1:0,1:1,2:1,1:2 and 0:1 .Coarse aggregate (dolomite, gravel) of $20 \mathrm{~mm}$ M.N.S mixed with cement, sand, ,water hyacinth of various ratios and water, the mix was $400 \mathrm{Kg}$ cement, $1200 \mathrm{Kg}$ total coarse aggregate and $600 \mathrm{Kg}$ sand per cubic meter of concrete at $\mathrm{w} / \mathrm{c}=0.50$ These constituents of concrete were mixed in mixer for two minutes, and then placed in cube moulds $10 \times 10 \times 10 \mathrm{~cm}$ for Isat, sorpitivity and compressive strength testing, whereas, the specimens for splitting tensile testing were cylinders $10 \times 20 \mathrm{~cm}$. Table 4 presents the masses of materials used $\left(\mathrm{kg} / \mathrm{m}^{3}\right)$.

\subsubsection{Testing}

In this research work, slump test carried as workability, whereas, the following tests on hardened concrete were carried out:

(a) Compressive strength: The compressive strength test was carried out according to the Egyptian Standard Specifications ESS 1658/2006 [6].To evaluate concrete compressive strength at test ages of 7,28 and 90 days.

(b) Splitting tensile strength: The splitting tensile strength test was carried out at 28 days age according to the Egyptian Standard Specifications ESS1658/2006[6].

(c) Initial surface absorption test ( Isat): At age of testing ( 28 days ), the tested cubes were oven dried at $105^{\circ} \mathrm{C}$ until reaching constant weight. Then, the dried specimens were left in a closed container for 24 hours until full stabilization.
To avoid the effect of moisture, silica gel was put in small pots in the same container beside the specimens.

TABLE 4, Mix proportions of concrete, $\mathrm{Kg} / \mathrm{m}^{3}$ at $400 \mathrm{Kg}$ cement $/ \mathrm{m}^{3}, 0.50 \mathrm{w} / \mathrm{c}$

\begin{tabular}{|c|c|c|c|c|}
\hline Mix code & C.agg. & Sand & $\begin{array}{c}W \\
-H \%\end{array}$ & G: D \\
\hline $\mathrm{G}$ & \multirow{25}{*}{1200} & \multirow{25}{*}{600} & 0 & $1: 0$ \\
\hline $\mathrm{D}$ & & & 0 & $0: 1$ \\
\hline G1D1 & & & 0 & $1: 1$ \\
\hline G1D2 & & & 0 & $1: 2$ \\
\hline G2D1 & & & 0 & $2: 1$ \\
\hline G & & & 0.5 & $1: 0$ \\
\hline $\mathrm{D}$ & & & 0.5 & $0: 1$ \\
\hline G1D1 & & & 0.5 & $1: 1$ \\
\hline G1D2 & & & 0.5 & $1: 2$ \\
\hline G2D1 & & & 0.5 & $2: 1$ \\
\hline G & & & 1 & $1: 0$ \\
\hline $\mathrm{D}$ & & & 1 & $0: 1$ \\
\hline G1D1 & & & 1 & $1: 1$ \\
\hline G1D2 & & & 1 & $1: 2$ \\
\hline G2D1 & & & 1 & $2: 1$ \\
\hline $\bar{G}$ & & & 2 & $1: 0$ \\
\hline $\mathrm{D}$ & & & 2 & $0: 1$ \\
\hline G1D1 & & & 2 & $1: 1$ \\
\hline G1D2 & & & 2 & $1: 2$ \\
\hline G2D1 & & & 2 & $2: 1$ \\
\hline $\mathrm{G}$ & & & 5 & $1: 0$ \\
\hline $\mathrm{D}$ & & & 5 & $0: 1$ \\
\hline G1D1 & & & 5 & $1: 1$ \\
\hline G1D2 & & & 5 & $1: 2$ \\
\hline G2D1 & & & 5 & $2: 1$ \\
\hline
\end{tabular}

The test period (2 hours), this test was carried out according to BS 1881: part 208-1996[ 7 ].

( d) Sorptivity test: The specimen preparation was carried out as the same of Isat, the test was carried out using a plastic container filled with water to a depth $20 \mathrm{~mm}$.Steel bars of $16 \mathrm{~mm}$ diameter were rested on the bottom of the container such that, the water was just above the top surface of the steel bars .The specimens were weighted using digital electric balance of $0.05 \mathrm{gm}$ accuracy. All surfaces around the chosen surface were then greased to about $2 \mathrm{~cm}$. The weights of the specimens were measured after removing the surface water at periods of 15 minutes up to 2 hours. The total amount of water absorbed was then monitored .The sorptivity of the tested specimens was calculated using the following equation [8 ]:
$\mathrm{i}=\mathrm{A}+\mathrm{s} \mathrm{t}^{0.5}$
.......(1) , where

$\mathrm{A}$, is constant,

$\mathrm{i}$, is the increase in mass in $\mathrm{g} / \mathrm{mm}^{2}$,

$\mathrm{t}$, is the time, measured at which the weight is determined,

$\mathrm{s}$, is the sorptivity in $\mathrm{mm} / \mathrm{sec}^{0.5}$ 
Xrd was applied on three specimens of $1 \% \mathrm{~W}-\mathrm{H}$ at gravel/ dolomite ratios of 1:0, $1: 1$ and $0: 1$, respectively. TGA (Thermo- Gravimetric Analysis) was carried out on cylindrical cement paste specimens $(50 \mathrm{~mm}$ diameter and 5 $\mathrm{mm}$ height), with different percentage of water hyacinth to determine the amount of hydration product in cement mixes. These specimens were cast in PVC molds after the end of curing period (28) days, the specimens were weighted in saturated surface dry (SSD) condition, then the specimens were put in an electric oven with surface temperature up to $1200^{\circ} \mathrm{C}$. The weight of specimens were recorded at various temperatures $(105,250,450,600,700,900$ and 950), then the weight loss resulted from the decomposition of matrix were used for calculating their different phases of hydration products. This method was followed by [9] and [10], where $\mathrm{C}-\mathrm{S}-\mathrm{H}$ decomposes at range $105^{\circ}-250^{\circ}, \mathrm{C}-\mathrm{H}$ decomposes at range of $450^{\circ}-600^{\circ}$, all non-evaporable water (NEW), bound water release at $950{ }^{\circ} \mathrm{C}$. The test specimens and age of testing is presented in Table 5 .

TABLE 5, , The test specimens and age of testing

\begin{tabular}{|l|c|c|}
\hline Test & $\begin{array}{c}\text { Test } \\
\text { specimen }\end{array}$ & $\begin{array}{c}\text { Age of } \\
\text { testing }\end{array}$ \\
\hline $\begin{array}{c}\text { Compressive } \\
\text { strength }\end{array}$ & $\begin{array}{c}100 \mathrm{~mm} \\
\text { cube }\end{array}$ & $\begin{array}{c}7,28 \text { and } \\
90 \text { days }\end{array}$ \\
\hline $\begin{array}{c}\text { Splitting tensile } \\
\text { strength }\end{array}$ & $\begin{array}{c}\text { Cylinder } \\
\text { of } 100 \mathrm{~mm} \\
\text { diameter and } \\
200 \mathrm{~mm} \text { length }\end{array}$ & 28 days \\
\hline Isat & $\begin{array}{c}100 \mathrm{~mm} \\
\text { cube }\end{array}$ & 28 days \\
\hline TGA & $\begin{array}{c}5 \mathrm{~cm} \\
\text { diameter,0.5 cm } \\
\text { thickness }\end{array}$ & 28 days \\
\hline Xrd & - & 28 days \\
\hline
\end{tabular}

\section{Test results and discussions}

\subsection{Slump}

The effect of water hyacinth on slump of concrete admixed with various gravel/dolomite ratios is presented in Figure 1 .It is apparent from this Figure that, increasing water hyacinth ratios in concrete mix led to decreasing slump, where the lowest values of slump at $5 \% \mathrm{~W}-\mathrm{H}$ ratio. This result is contrary to the result obtained by [2].

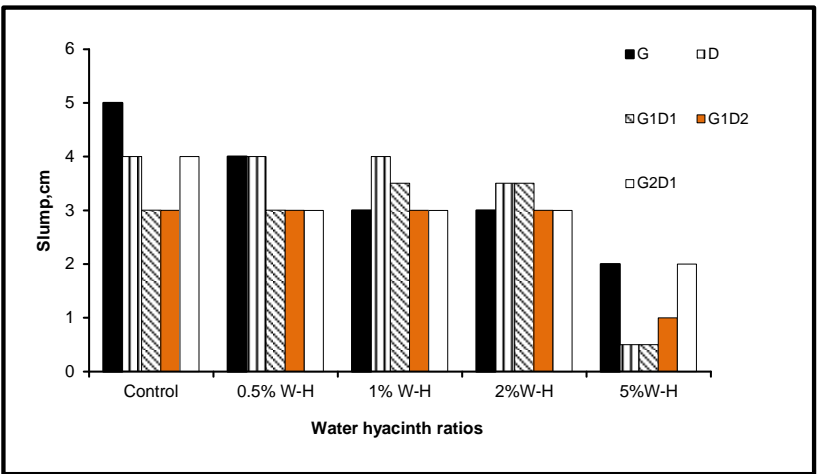

Figure 1 , Effect of water hyacinth ratios on slump of concrete made with various gravel/ dolomite ratios.

\subsubsection{Hydration of Cement}

Table 6 represents the impact of water hyacinth ratios on hydration products of cement, it is apparent that the maximum decomposition of weight due to $\mathrm{C}-\mathrm{S}-\mathrm{H}$ observed at $5 \% \mathrm{~W}-\mathrm{H}$ ratio whereas, the maximum decomposition of weight due to $\mathrm{C}-\mathrm{H}$ obtained at control mix, where water hyacinth decreased $\mathrm{C}-\mathrm{S}-\mathrm{H}$ in concrete mix, whereas W-H increased NEW. The maximum NEW exhibited at $2 \% \mathrm{~W}-$ $\mathrm{H}$, otherwise, minimum NEW is observed at control mix.

TABLE 6, Decompositions due to C-S-H, C-H and NEW, bound water, $\%$ for different mixes.

\begin{tabular}{|c|c|c|c|}
\hline Code mix. & $\begin{array}{c}\text { Weight } \\
\text { loss due to } \\
\text { decomposition } \\
\text { of C-S-H,\% }\end{array}$ & $\begin{array}{c}\text { Weight loss } \\
\text { due to } \\
\text { Decomposition of } \\
\text { C-H,\% }\end{array}$ & $\begin{array}{c}\text { NEW, } \\
\text { bound } \\
\text { water, \% }\end{array}$ \\
\hline Control & 8 & 6.1 & 30.7 \\
\hline W-H- 0.5\% & 9.83 & 2.62 & 32.78 \\
\hline W-H 1\% & 3.66 & 5.33 & 30.67 \\
\hline W-H 2\% & 7.82 & 2.28 & 33.87 \\
\hline W-H 5\% & 11.42 & 2.57 & 33.14 \\
\hline
\end{tabular}

\subsubsection{X-Ray Diffraction}

Figures 2 to 4 represent the Xrd for specimens treated with gravel /dolomite 1:0,0:1 and $1: 1$ at $1 \% \mathrm{~W}-\mathrm{H}$ ratio, it is apparent from these Figure that, $\mathrm{C}-\mathrm{S}-\mathrm{H}$ inhibited in concrete specimen made with gravel, whereas, C-S-H exhibited in concrete specimens admixed with $\mathrm{G}$ : $\mathrm{D}=1: 1$ and dolomite, respectively.

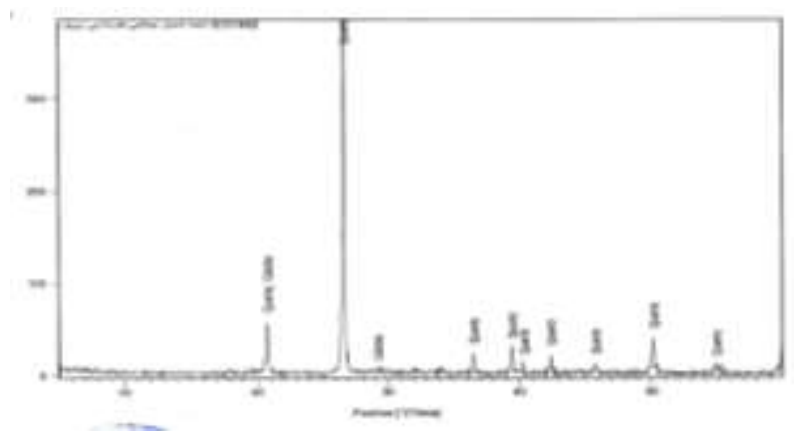

Figure 2, Xrd for concrete specimens made with gravel at $1 \%$ of W-H.

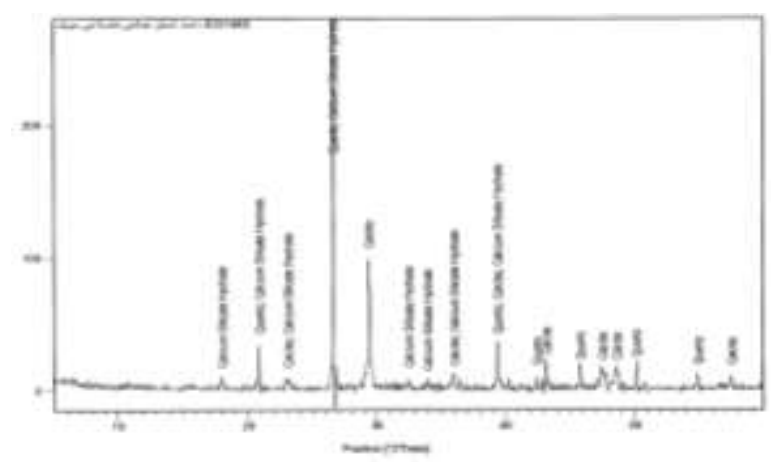

Figure 3, Xrd for concrete specimens made with dolomite at $1 \%$ of W-H 


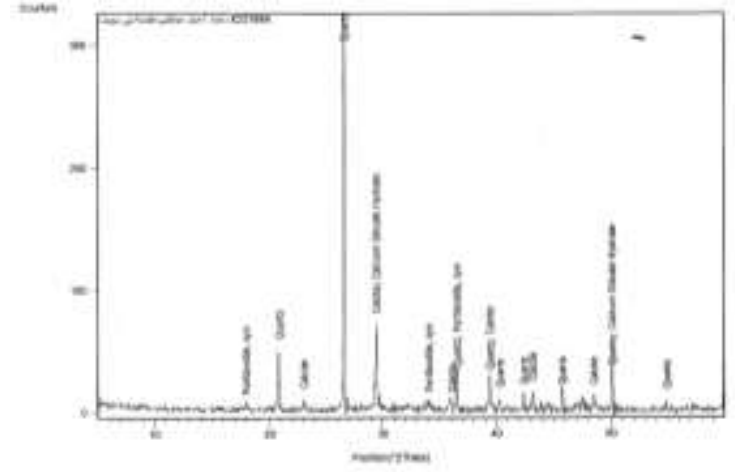

Figure 4, Xrd for concrete specimens made with gravel: dolomite $=1: 1$ at $1 \%$ of $\mathrm{W}-\mathrm{H}$.

\subsubsection{Initial surface absorption test}

The influence of $2 \%$ water hyacinth on flow rate by Isat of concrete admixed with various gravel/dolomite ratios is presented in Figure 5, it is observed from this Figure that, the peak flow rate of concrete exhibited at dolomite, whereas, the lowest value observed at gravel.

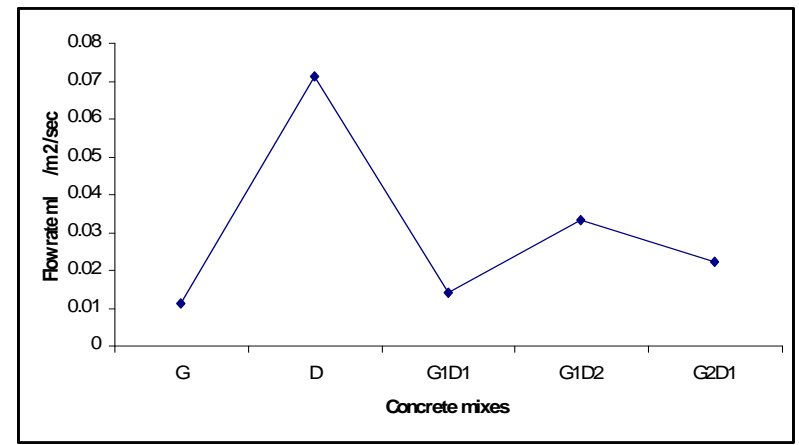

Figure 5, Effect of water hyacinth ratios on flow rate of concrete made with various gravel/ dolomite ratios.

\subsubsection{Compressive strength}

Figures 6 to 11 represent the impact of water hyacinth percentage on compressive strength of concrete made with different gravel/dolomite ratios, it is apparent from these Figures, that increasing the age, the compressive strength of concrete with various $\mathrm{W}-\mathrm{H}$ ratios increased. The maximum increasing observed at $2 \% \mathrm{~W}-\mathrm{H}$ at dolomite mix followed by $\mathrm{G} / \mathrm{D}=1: 2$, this result may be attributed to the maximum NEW observed at $2 \% \mathrm{~W}-\mathrm{H}$, texture of dolomite. Compared to concrete made with gravel, various mixes discussed increased the compressive strength of concrete with different $\mathrm{W}-\mathrm{H}$ ratios except that for $\mathrm{G} / \mathrm{D}=2: 1$. This result is contrary with the result obtained by Isat which showed that lowest water flow exhibited at gravel.

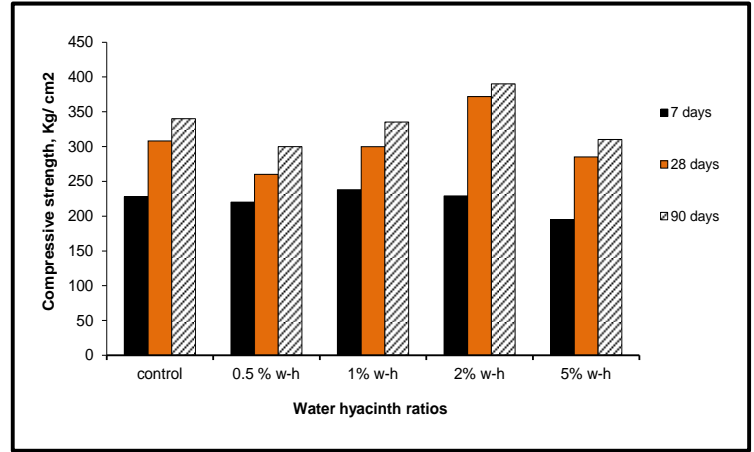

Figure 6, Effect of water hyacinth ratios on compressive strength of concrete made with gravel at different ages.

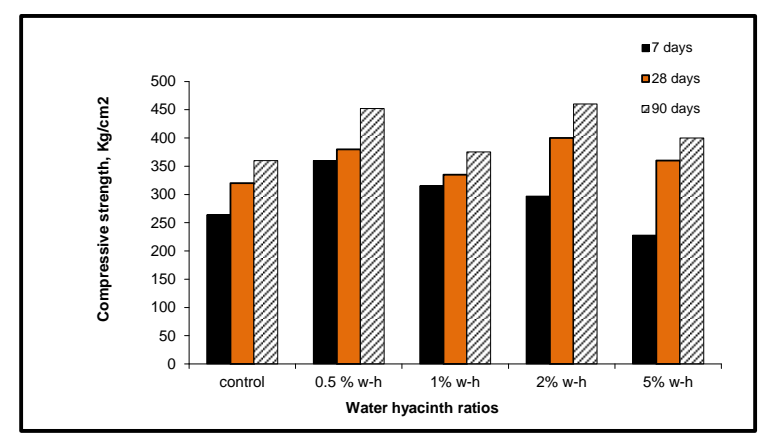

Figure 7 , Effect of water hyacinth ratios on compressive strength of concrete made with dolomite at different ages.

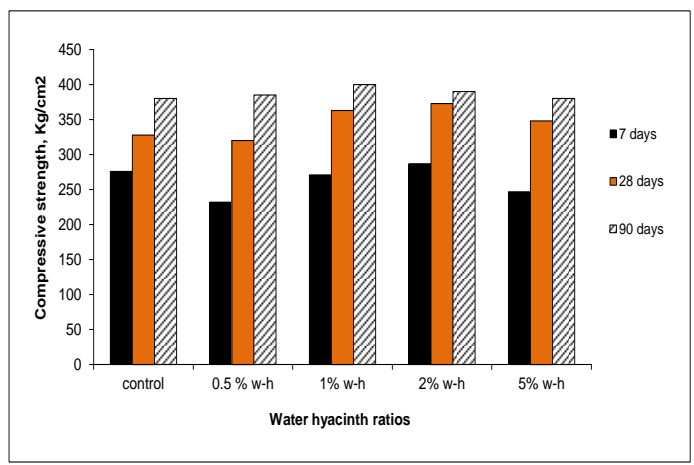

Figure 8 , Effect of water hyacinth ratios on compressive strength of concrete made with gravel/ dolomite $=1: 1$ at different ages.

\subsubsection{Splitting tensile strength}

Figure 12 represents the impact of percentage of water hyacinth on splitting tensile strength of concrete admixed with various gravel/ dolomite ratios. It is apparent from this Figure, that the maximum splitting tensile strength is exhibited at $\mathrm{D}$ and $\mathrm{G} / \mathrm{D}=1: 2$ at $2 \% \mathrm{~W}-\mathrm{H}$, whereas, the minimum splitting tensile strength observed at $\mathrm{G}: \mathrm{D}=2: 1$. 


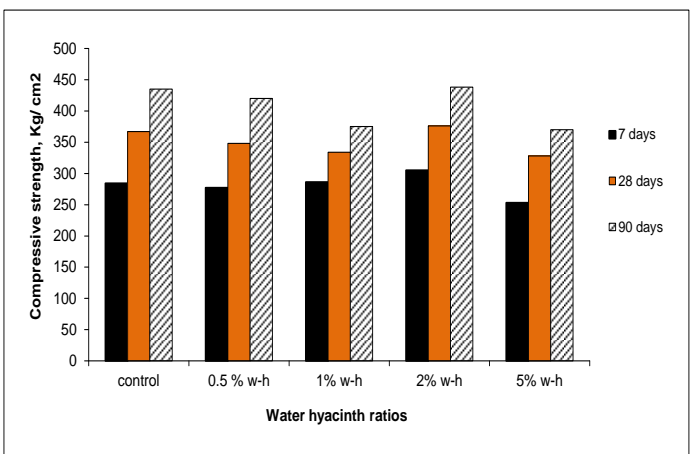

Figure 9 , Effect of water hyacinth ratios on compressive strength of concrete made with gravel/ dolomite $=1: 2$ at different ages.

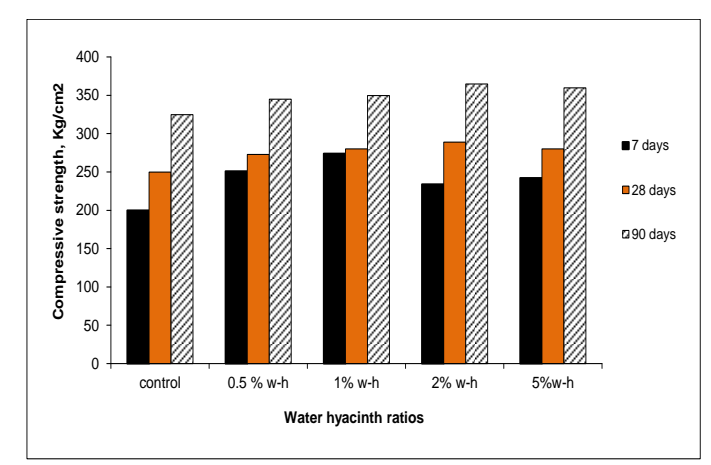

Figure 10, Effect of water hyacinth ratios on compressive strength of concrete made with gravel/ dolomite $=2: 1$ at different ages.

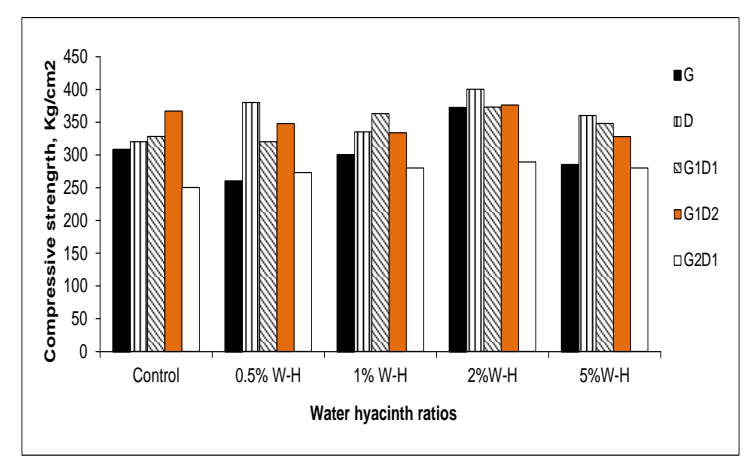

Figure 11, Effect of water hyacinth ratios on compressive strength of concrete made with various gravel/ dolomite ratios at 28 days.

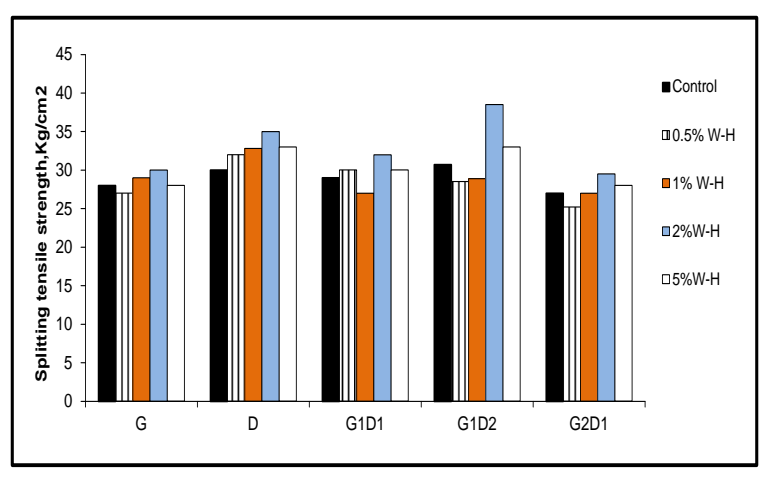

Figure12, Effect of water hyacinth ratios on splitting tensile strength of concrete made with various gravel/ dolomite ratios at 28 days.

\section{CONCLUSIONS}

Based on this experimental study, the following conclusions can be drawn:

1-Introducing $\mathrm{W}-\mathrm{H}$ in concrete mix up to 2 by mass of cement not affected the slump whereas, compared to reference concrete $5 \% \mathrm{~W}-\mathrm{H}$ decreased the slump.

2- Compared to various Gravel: dolomite ratios, $\mathrm{G}: \mathrm{D}=1: 2$ led to decreasing the slump to lowest value.

3- Introducing $\mathrm{W}-\mathrm{H}$ in concrete mix decreased $\mathrm{C}$ $\mathrm{H}$, developed NEW, bound water, $\%$.

4- Mass transport properties of concrete not affected the compressive strength of concrete containing water hyacinth, whereas, microstructure affected it.

5- The compressive strength of concrete c containing water hyacinth is developed by increasing concrete age .

6- Introducing ddolomite in concrete mix enhanced the compressive strength, the maximum compressive strength observed at $2 \% \mathrm{~W}-\mathrm{H}$, the lowest compressive strength exhibited at $\mathrm{G}: \mathrm{D}=2: 1$.

7- The maximum splitting tensile strength occurred at $2 \% \mathrm{~W}-\mathrm{H}$ at dolomite and $\mathrm{G}: \mathrm{D}=1: 2$.

\section{REFRENCES}

[1] C. Arum, and A.O.Olotuah, Making of strong and durable concrete",Emirates J.Eng. Res.,11,pp 25-31,2006.

[2] P. Sathya.Bhuvaneshwari, G. Niranjan, and M.Vishveswaran, "Influence of Bio Admixture on Mechanical Properties of Cement and Concrete", Asian Journal of Applied Science, 7(4), pp. 205-214,2014.

[3] A.F.M Omran, , Y.B Shaheen, , M.M Kamal, and M.A Osman, "Feasibility of using W-H as concrete admixtures",M.S thesis,Faculty of engineering,minufiya university,250 p.p.,2003.

[4] A.H Makhlouf, A.G. Hadhod, and M.A. ELSAYED, "Application of W-H ash as a partial replacement for cement",Ph.D thesis, Faculty of engineering, cairo university,210 p.p.,2002.

[5] ESS 2421/2005-Egyptian standard specification, cement-physical and mechanical testing.

[6] ESS 1658/2006- Egyptian standard specification, testing of concrete.

[7] B.S 1881: part 208-1996-Testing concrete-Recommendations for the determination of the initial surface absorption of concrete.

[8] C.Hall, ," Water sorptivity of mortars and concrete: a review, Magazine of Concrete Research, Vol.41,issue 147,pp.51-61,1989.

[9] A.A Rahman, and F.P. Glasser ," Comparative studies of the carbonation of hydrated cements", Advanced in Concrete Research,Vol.2,No.6,pp.49-54,1989.

[10] G.E Abdelaziz ," Microstructural analysis of surface and interface zones in concrete",ph.D.Thesis,Aston University,UK,250 pp,1998. 